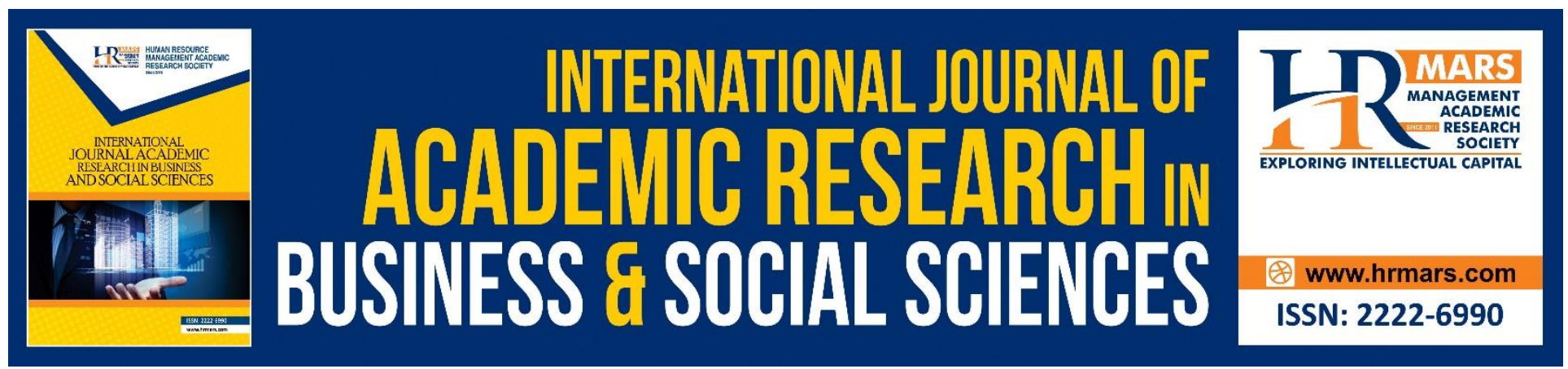

\title{
E-Government Services Implementation: Is it a Need?
}

Syafila Kamarudin, Siti Zobidah Omar, Jusang Bolong \& Mohd Nizam Osman

To Link this Article: http://dx.doi.org/10.6007/IJARBSS/v8-i11/4881

DOI: $10.6007 /$ IJARBSS/v8-i11/4881

Received: 16 Sept 2018, Revised: 11 Oct 2018, Accepted: 16 Oct 2018

Published Online: 21 October 2018

In-Text Citation: (Kamarudin, Omar, Bolong, \& Osman, 2018)

To Cite this Article: Kamarudin, S., Omar, S. Z., Bolong, J., \& Osman, M. N. (2018). E-Government Services Implementation: Is it a Need? International Journal of Academic Research in Business and Social Sciences, 8(11), 22-29.

Copyright: (C) 2018 The Author(s)

Published by Human Resource Management Academic Research Society (www.hrmars.com)

This article is published under the Creative Commons Attribution (CC BY 4.0) license. Anyone may reproduce, distribute, translate and create derivative works of this article (for both commercial and non-commercial purposes), subject to full attribution to the original publication and authors. The full terms of this license may be seen at: http://creativecommons.org/licences/by/4.0/legalcode

Vol. 8, No. 11, 2018, Pg. 22 - 29

http://hrmars.com/index.php/pages/detail/IJARBSS

JOURNAL HOMEPAGE

Full Terms \& Conditions of access and use can be found at http://hrmars.com/index.php/pages/detail/publication-ethics 


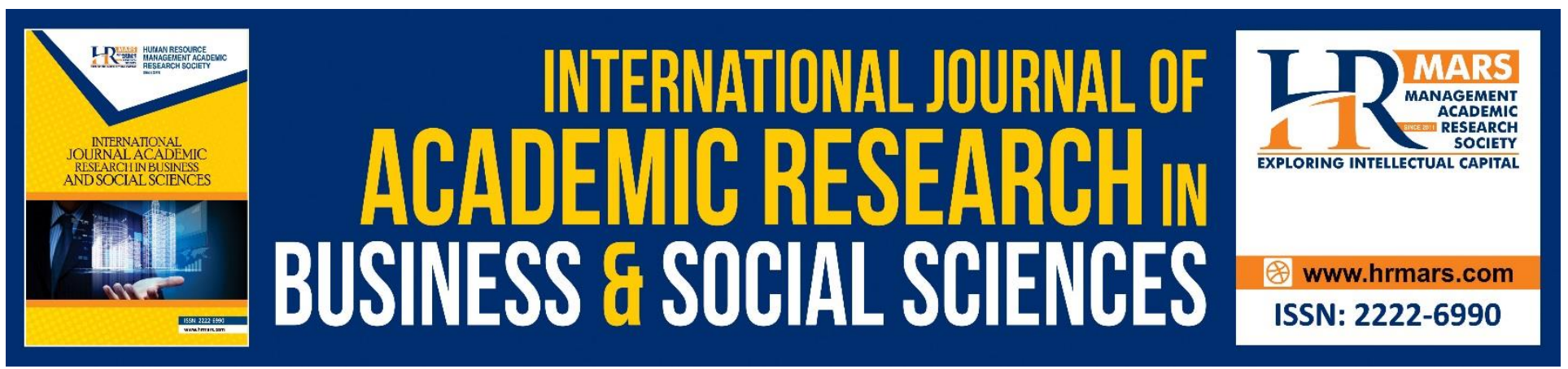

\title{
E-Government Services Implementation: Is it a Need?
}

\author{
Syafila Kamarudina, Siti Zobidah Omara,b, Jusang Bolong ${ }^{b}$ \& Mohd \\ Nizam Osman ${ }^{b}$ \\ alnstitute for Social Science Studies, Universiti Putra Malaysia, 43400 Serdang, Selangor. \\ b Faculty of Modern Languages and Communication, Universiti Putra Malaysia, 43400 Serdang, \\ Selangor. \\ Email: syafila.kamarudin@gmail.com
}

\begin{abstract}
The Malaysian government has initiated e-service to embrace the use of modern information communication technology (ICT) in delivering services to its citizen. One of its e-service provider pertaining to online government service is My E.G. Services Berhad; which was established in 2000. It is a private company which has been given a concession by the government to conduct an online government transactions services. This article discussed on the use of MyEG services that will be viewed from the development perspective that took place, especially in Malaysia. In addition, it also discussed on the concept of e-government and the implementation that has yet to be undertaken in order to ensure the MyEG services can be used optimally in the course of daily work.
\end{abstract}

Keywords: E-Government, E-Service, Information Communication Technology, Online, Development

\section{Introduction}

The world is moving towards industrial revolution (IR 4.0) which has brought great changes in the country. Various efforts have been undertaken by the government to make Malaysians apply information communication technology (ICT), particularly in terms of government services. In accordance with the launch of the Multimedia Super Corridor (MSC) in 1996, MSC is in its third phase (2011-2020) of its inception (Noraidah Sahari et al. 2011) targeted to transform of Malaysian into a knowledge-based society. Moreover, implementation of ICT in the government sector may lead to the national economic growth.

MSC provides the necessary platform to promote the development of the ICT industry. This environment allows people to gain easy access and the opportunity to participate in new opportunities created by the economic growth of the country. ICT is capable in acting as an important tool in searching for information for the community in strengthening their skills and knowledge (Siti Zobidah Omar et al., 2012). The desire to create knowledgeable citizens in the world of ICT will be easily achieved with the space and facilities provided by the government. If viewed from the 
INTERNATIONAL JOURNAL OF ACADEMIC RESEARCH IN BUSINESS AND SOCIAL SCIENCES Vol. 8, No. 11, Nov, 2018, E-ISSN: 2222-6990 @ 2018 HRMARS

perspective of the prime application of MSC, there are seven innovative flagship applications that have been developed. These applications are engineered to jump start the MSC initiative and create a multimedia utopia for innovative producers and users of multimedia technology. In short, this prime application is as shown in Table 1 below.

Table 1: MSC Prime Application

\begin{tabular}{|c|c|}
\hline Application & Description \\
\hline Multi-purpose card & $\begin{array}{l}\text { - As a credit card and electronic purse. } \\
\text { - Contains information such as Health and Insurance Policy number. }\end{array}$ \\
\hline Smart school & $\begin{array}{l}\text { - All schools have internet facilities and computer labs. } \\
\text { - The Ministry of Education prepares a guideline for new curriculum and } \\
\text { develops the content of learning application. }\end{array}$ \\
\hline Tele-health & $\begin{array}{l}\text { - Ensures MSC serves as a regional center for tele-medicine to enable all } \\
\text { patients and medical specialists to receive online consultation service } \\
\text { through multimedia facilities. }\end{array}$ \\
\hline Cluster R\&D & $\begin{array}{l}\text { - R\&D center is developed in MSC to seek opportunities for cooperation } \\
\text { with other centers all over the world in fields of engineering, } \\
\text { construction and design works. }\end{array}$ \\
\hline E-business & - Web global manufacturing and marketing center without boundaries. \\
\hline \multirow[t]{2}{*}{ E-government } & - Government departments function online. \\
\hline & - Services and relations made electronically. \\
\hline
\end{tabular}

Source: Multimedia Super Corridor (2012)

In January 2006, the government called for all public services to allow consumers to pay bills online (Economist Intelligence Unit, 2006). The provider of the online government service is the My E.G. Services Berhad which was established in year 2000. It is a private company which has been given a concession by the government to conduct online government transactions services. The Government introduced MyEG application as a tool to enable people when dealing with government. The MyEG system links users to various government agencies such as the Road Transport Department (JPJ), Royal Malaysia Police (PDRM), Kuala Lumpur City Hall, National Registration Department, the Department of Insolvency Malaysia (JIM), Immigration Department of Malaysia, and Zakat. Besides the purpose to increase the use of ICT among citizens and businessmen, MyEG application is also able to reduce the digital gap among Malaysians. This initiative offered is able to save time and energy since users do not need to go to the counter for government matters.

With the facility of MyEG application, people are able to accelerate their daily matters. This indirectly encourages the public to use new technology as part of their daily activities. MyEG application can be easily accessed by any users, regardless of their location. A study by Akther et al. (2009) explained that there was no difference in terms of desire to use e-government for those who reside in rural and urban areas. However, the desire to use e-government is different for ICT users residing in urban and rural areas. This is because the widespread of internet access is a prerequisite for e-government system that includes the use of MyEG application. The internet usage in Malaysia for home users also differs between urban and rural areas. According to Hamizah Sahharon et al. 
(2014), the need of rural communities for online activities such as registration, payment and revisions showed an increase in the e-development efforts of the government. Therefore, MyEG application is an appropriate tool for them to obtain any information related to the government. This situation provides convenience for people to use them no matter where they are.

This article talks about the implementation of the Malaysia's e-government services delivered by MyEG application. A few other matters were also discussed by researchers such as the execution of MyEG application and recommendations for future research. Therefore, this article uses the literature review as a reference. The researchers adjusted the current situation with the findings of other researchers in the previous studies.

\section{Malaysia's E-Government Service}

There are various interpretations of previous researchers regarding the definition of e-government. The most discussed definitions have almost the same meaning which is the facilities granted by society to an electronic system provided. In this study, it is generally understood that e-government is the government's strategy to focus on the rights of citizens which involves managing government services.

According to Fang (2002), e-government can be defined as a measure for the government to use the most innovative information and communication technology in the form of web-based internet applications, to provide ease of access to citizens and businesses, particularly relating to information and government services. In addition, Fang (2002) went on to add that the existence of e-government can improve service quality and provide greater opportunities for the public to participate in the institutions and also to the democratic process. Ndou (2004), on the other hand, defined e-government as a government-owned or systems that handle information and communication technologies that transform relations with its citizens, the private sector and government agencies in order to promote empowerment of citizens, improve service quality, strengthen accountability, improve transparency and improve government efficiency.

Through above said definitions, there are several target groups aimed by the government for the use of e-government. The target groups are divided into three, namely between government and other government agencies (G2G), between government and citizens (G2C) and between government and businesses / commerces (G2B). This is explained by Lean et al. (2009) who stated that e-government is an initiative that aims to improve the quality of interaction between governments, citizens and businesses. This improvement depends on the communication system, providing good access, high quality service and a reliable processing system. Study by Hasmiah Kasimin et al. (2011) proved that e-government is a communication facility between government and citizens, also to the business community through online services offered by the government.

The implementation of e-government aims to improve the efficiency, effectiveness and sustainable public services in line with national goals. In addition, e-government has the potential to build stronger institutional capacity for better service delivery to citizens and businesses. This can help reduce the potential for corruption prevailing in the country by increasing the transparency and social control (Ronaghan, 2002). When government receives an overwhelming response from various parties, the government expects that e-government is able to establish a good interaction between the parties involved. According to Evans \& Yen (2006) e-government is a digital two-way interaction 
between the government and the people in building a good relationship between the two. This relationship makes interaction more effective in terms of delivery of information. Warkentin et al. (2002) stated that among the characteristics of an effective e-government are the wide use of communication technology, online environment, data collection facilities and user-friendliness.

Therefore, in order to move forward with the e-government activities, the basic factor that should exist in every individual is the internet facility (DeBenedict et al., 2002). DeBenedict et al. (2002) explained that e-government is the use of internet-based information technology in improving the quality of government services. The presence of the internet is the most important factor in revolutionizing the business of government in making service activities more important (Ahmad Syahrul Haniff Mohd Rawi et al., 2012). The existence of e-government services is able to indirectly optimise business conducts by minimising the use of time and space.

\section{Internet is the base for Online Activities}

Malaysian Institute of Micro Electronic System (MIMOS) pioneered the internet in Malaysia by introducing the Malaysia Computer Network (RangKom) in 1987 (Adnan Hussein \& Kamaliah Siarap, 2000). The internet has developed in terms of infrastructure and the use is in line with current needs. For example the internet usage in the United States is very widespread, has a remarkable improvement phenomenon after the 1990s and it overcomes other electronic equipment such as televisions and telephones (Gross, 2010). The number of internet users in Malaysia, on the other hand, has reached 17.7 million people in June 2012 (Internet World Stats, 2014). According to Malaysian Communications and Multimedia Commission (2016), Malaysia users spend an average of 12 hours a week surfing the internet. It shows that the use of internet in Malaysia is high and in demand.

In March 2010, there was a significant increase of 96,214 registrations indicated for Malaysia domain name usage rights successfully listed (Internet World Stats, 2014). The increment shows that many parties were aware of the advantages of internet services, particularly for activities involving dealings with the government. According to Leiner et al. (2009) internet was the most successful example through its advantages in maintaining its commitment to research and development in the information infrastructure. In fact, the internet is a manifestation of the growth in terms of development and as an enabler for innovation. This includes the aspects of infrastructure, applications, user services, as well as technological innovation (Kleinrock, 2008).

According to the International Telecommunication Union (2010), the number of internet users in 2010 surpassed the total of 2 billion of which 1.2 billion of this total is from developing countries, including Malaysia. Thus, with the growing number of users utilise the internet, there is a high potential for further develoment of e-government. Moreover, the internet is a base for the establishment of electronic services networks.

\section{The Implementation of E-government Application}

Previous studies discussed issues related to the implementation and use of e-government services from various forms of government applications. As an example, Norashikin Zainal Abidin et al. (2011) conducted a research on e-government and e-consumers culture among Malaysians youth. They conclude that there was a level of need among e-users to use the e-government system. Similar to 
the empirical study conducted by Maizatul Haizan Mahbob et al. (2011) on public service innovation through the implementation of e-government. The study focused on the acceptance and implementation of e-services in the Klang Valley. On the other hand, Hung et al. (2006) studied the critical factors for the acceptance of e-government services in Taiwan. These researchers examined from the perspective of online tax filing and payment system by the youth there.

\section{Conclusion and Recommendation}

In general, e-government in the context of MyEG application is one of the initiatives of the government to the people. The government believes that this effort as an amenity for the people and the business community in solving a wide variety of matters. It is important for every consumer to understand the concept of online service before they conduct any transaction. The development of e-government in Malaysia is already at the growing stage. With the initiative of the government to ensure that e-government application is fully utilised by people in Malaysia, various frameworks and infrastructure construction has been and will be developed later. It is in line with the rapid development of e-government that has been adopted by some developed and developing countries to stimulate their economies.

Among the proposals for future research studies on MyEG application is the recommendation to look into the factors that influence consumer acceptance of MyEG application. In addition, future researchers can also examine the factors that influence the acceptance and contribution to the highest value of the acceptance to the use of MyEG application in Malaysia.

\section{Contribution}

It is hoped that this study could form a theoretical framework for testing the relationship between the level of user and their acceptance of e-government by using appropriate theories such as the unified theory of acceptance and use of technology (UTAUT) and technology acceptance model (TAM). In addition, the contextual aspects, this study can see how e-government usage patterns such as MyEG application by the society. The use of e-government today is significant in facilitating consumers to deal with the government.

\section{Acknowledgement}

This research was funded by UPM research grant GP-IPS/2017/9547200.

\section{References}

Hussein, A. \& Siarap, K. (2000). Penggunaan teknologi komunikasi-informasi di kalangan ahli akademik di Malaysia. Jurnal Komunikasi, Malaysian Journal of Communication, 16(1), 119130.

Akhter, M. S., Onishi, T., \& Kidokoro, T. (2009). Demand Analysis of E-Government in Developing Countries, Available Online: http://miha2.ef.uni-lj.si/cost298/gbc2009proceedings/papers/P032.pdf

DeBenedictis, A., Howell, W., Figueroa, R., \& Boggs, R. (2002). E-government defined: an overview of the next big information technology challenge. Issues in Information Systems, 3(1), 130-136. 
Economist Intelligence Unit. (2006). Overview of e-commerce in Malaysia. Diakses pada 29 Ogos 2016. http:// globaltechforum.eiu.com/index.asp?layout $1 / 4$ printer_friendly\&doc_id $1 / 48706$

Evans, D., \& Yen, D. C. (2006). E-Government: Evolving relationship of citizens and government, domestic, and international development. Government Information Quarterly, 23(2), 207-235.

Fang, Z. (2002). E-government in digital era: concept, practice, and development. International Journal of the Computer, the Internet and Management, 10(2), 1-22.

Gross, L. S. (2010). Electronic Media. New York: McGrew-Hill.

Hung, S. Y., Chang, C. M., \& Yu, T. J. (2006). Determinants of user acceptance of the e-government services: The case of online tax filing and payment system. Government Information Quarterly, 23(3), 97-122.

International Telecommunication Union. (2010). The World in 2010. Accessed on 26 $6^{\text {th }}$ March 2015 from http://www.itu.int/ITU-D/ict/material/FactsFigures2010.pdf

Internet World Stats. (2014). Usage and Population Statistics. Accessed on $29^{\text {th }}$ August 2016 from http://www.internetworldstats.com/asia.htm\#my

Kleinrock, L. (2008). History of the Internet and Its Flexible Future. IEEE Wireless Communications, 15(1), 8-18.

Lean, O. K., Zailani, S., Ramayah, T., \& Fernando, Y. (2009). Factors influencing intention to use egovernment services among citizens in Malaysia. International Journal of Information Management, 29(6), 458-475.

Leiner, B. M., Cerf, V. G., Clark, D. D., Kahn, R. E., Kleinrock, L., Lynch, D. C., \& Wolff, S. (2009). A brief history of the Internet. ACM SIGCOMM Computer Communication Review, 39(5), 22-31.

Malaysian Communications and Multimedia Commission. (2016). Internet users survey 2016.

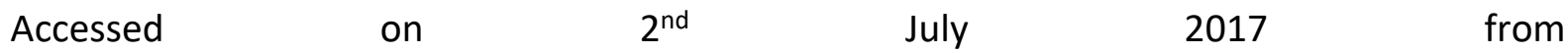
https://www.mcmc.gov.my/skmmgovmy/media/General/pdf/IUS2016.pdf

Multimedia Super Corridor. (2012). Accessed on $17^{\text {th }}$ July 2017 from http://nurelimtiaz.uitm.edu.my/wordpressfolder-elimtiaz/wpcontent/uploads/2012/08/MSC.pdf

Ndou, V. (2004). E-government for developing countries: opportunities and challenges. The Electronic Journal on Information Systems in Developing Countries 18(1), 1-24.

Ronaghan, S. A. (2002). Benchmarking e-government: a global perspective. Assessing the progress of the UN member states. United Nations Division for Public Economics and Public Administration \& American Society for Public Administration.

Warkentin, M., Gefen, D., Pavlou, P. A., \& Rose, G. M. (2002). Encouraging citizen adoption of egovernment by building trust. Electronic Markets, 12(3), 157-162.

\section{Contributors' Profiles:}

Syafila Kamarudin is currently a doctoral candidate at Institute for Social Science Studies, Universiti Putra Malaysia. Her main research interests include communication technology, e-government and rural advancement. 
Dr. Siti Zobidah Omar is a Deputy Director at the Institute for Social Science Studies (IPSAS), Universiti Putra Malaysia (UPM). She is also an Associate Professor at the Department of Communication, Faculty of Modern Languages and Communication, Universiti Putra Malaysia. Her research interests are related to communication technology and culture (use of ICT, mobile phone, e-community, ICT and gender).

Dr. Jusang Bolong is a Deputy Dean (Research and Inovation) at the Faculty of Modern Languages and Communication, UPM. He is also an Associate Professor at the Department of Communication, Faculty of Modern Languages and Communication, Universiti Putra Malaysia. His research interests include human communication, computer mediated communication, and development communication.

Dr. Mohd Nizam Osman is a senior lecturer at the Department of Communication, Faculty of Modern Languages and Communication, Universiti Putra Malaysia. His research interests include broadcasting, ICT and telecommunication. 